\title{
Phenotypic diversity of apricot cultivars derived from of Shalakh variety
}

\author{
Dzhalaludin Anatov ${ }^{1,2^{*}}$, and Ruslan Osmanov ${ }^{1}$ \\ ${ }^{1}$ Mountain Botanical Garden DFRC RAS, 75 str. Yaragskogo, Makhachkala, 36700, Russia \\ ${ }^{2}$ Dagestan Federal Research Centre RAS, 45 str. M. Gadjiev, Makhachkala, 367000, Russia
}

\begin{abstract}
The article presents the results of the pomological study of the cultivars of apricot derived from of Shalakh variety. The results of the analysis showed the presence of prevailing features of transmitted offspring from the desired variety. The best inheritability of the features of the Shalakh was traits of symmetry of fruit and stone $(100 \%)$, form hole shape of stone $(100 \%)$, shape of apex of stone $(100 \%)$, keel character of stone $(100 \%)$, depth of stalk cavity of fruit $(88.9 \%)$, shape of stone base (88.9\%), stone thickness $(77.8 \%)$, lateral ribs type of stone $(77.8 \%)$. The oblongness of the fruit and stone has poor or almost is not transmitted to the offspring from the Shalakh.
\end{abstract}

\section{Introduction}

Apricot (Prunus Armeniaca L.) is a valuable fruit culture from China and Central Asia, having a long history of cultivation and wide geographical distribution at present $[1,2,3,4$, $5,6]$.

This culture is most promising in the South of Russia, Crimea and the Caucasus [7]. In Dagestan, apricot is cultivated in the inland part along the valleys of the rivers Avarskoe Koisu, Andijskoe Koisu, Kazikumukhskoe Koisu and Kara-Koisu [8, 9].

Currently, the famous Armenian variety of Shalakh is more popular at Dagestan gardeners for its good taste and commodity qualities, large size of fruits and transportability. It has received a wide distribution in Untsuculsky, Gergebilsky districts and partly in the Gunibsky district at altitudes up to $900 \mathrm{~m}$, where it gives a high and regular harvest. Nevertheless, the Shalakh is low-yielding on the flatlands and piedmonts, which is associated with its self-sterility and low resistance of fungal diseases [10].

One of the most important attributes in creating new varieties are the characteristics of the fruit and stone which determines the commercial value for producers and attractiveness for the consumers [11].

In this regard, the selection breeding and assessment of the hybrid progenies of Shalakh variety on morphology, phenology and resistance has a practical importance for the Republic of Dagestan.

This work is devoted to a comparative assessment of the phenotypic diversity of some hybrids of Shalakh variety on morphological features of the fruit, stone and kernel using statistical analysis methods.

* Corresponding author: djalal@list.ru 


\section{Materials and methods}

The material for the study was 8 forms of apricot obtained from the intervarietal crossing of Shalakh variety (ㅇ) and the local varieties of Dagestan (a mixture of pollen). The resulting selections with the best characteristics were planted in a private garden in the village of Nizhny Chugli Levashinsky district. As a comparison were used the Shalakh variety and a promising variety from the Nikitsky Botanical Garden NSC of the RAS - Krymskiy Medunets, which has been obtained from the intervarietal crossing of varieties of Shalakh and Stepnyak [12].

Pomological traits of fruits and stones, their form is important in the determination of varieties [13]. The morphological description and gradation of traits are given for 34 qualitative features of the fruit and endocarp using well-known techniques $[14,15,16]$ with some additions.

The comparison of apricot cultivars was carried out according to the following quality characteristics: Fruit - size, shape in lateral view and shape in ventral view, symmetry, depth of stalk cavity, blotchness, shape of apex, presence of mucro, suture, ground color of skin, presence hue of over color and its size, color of flesh, consistency, taste, adherence of stone to flesh, ratio mass of stone/fruit; Endocarp - size, symmetry, shape, base form, presence spine by of hole, shape of base hole, form of apex, thickness, ribs width, lateral rib type, keel height (abdominal suture), keel type (degree intensity of abdominal suture), keel character, dorsal suture, surface color, outer surface, bitterness.

The grouping of cultivars on the results of the pomological description was carried out by cluster analysis using the Software of Statistica v.13.

\section{Results and discussion}

The high range of variability is observed by comparing the cultivars of apricot and Shalakh in the size of the fruit (Table 1). Thus, the fruits of the Shalakh are large, but most of the cultivars in general have smaller dimensions (about 78\%), which is consistent with the data on the inheritance of the fruit size, in which the high percentage (up to 30\%) of large-scale hybrids is obtained when crossing varieties with large fruits. The obtained result is quite natural considering the fact that many local varieties have the average size of the fruit. The best inheritability of the cultivars of the characteristics of the Shalakh, in addition to selectively directed selections (for consistency, taste, adherence of stone to flesh, bitterness), were founded for such diagnostic traits as symmetry of fruit and stone $(100 \%)$, form hole shape of stone $(100 \%)$, shape of stone apex $(100 \%)$, keel character $(100 \%)$, blotchness $(88.9 \%)$, shape of stone base $(88.9 \%)$, thickness of stone $(77.8 \%)$, lateral ribs type $(77.8 \%)$. It is known that yellow skin and the color of flesh of fruit dominate over orange [11]. The prevailing color of skin is orange and yellow-orange color of flesh as for Shalakh cultivars. Elliptical form of fruit and elongated shape of stone is bad or almost is not transmitted.

Clustering of samples by the Ward's method made it possible to select two clusters of 5 samples in each (Fig. 1). Clusters were grouped according to the traits: presence of fruit mucro, presence spine by of hole and surface of stone. The first cluster includes samples, in which fruit has a presence spine by of stone hole and strongly wrinkled of stone surface and no presence of fruit mucro. The differentiation between other traits was not statistical confidence. 
Table 1. Comparative characteristics of varieties of Shalakh and cultivars according to high-quality features of fruit

\begin{tabular}{|c|c|}
\hline Traits & Characteristics of cultivars, $\%$ \\
\hline \multicolumn{2}{|r|}{ Fruit } \\
\hline Size & Small $=11.1 ;$ medium $=66.7 ;$ large $=11.1 ;$ very large $=11.1$ \\
\hline Shape in lateral view & Circular $=77.8 ;$ ovate $=22.2 ;$ elliptic $=0$. \\
\hline Shape in ventral view & Circular $=44.4 ;$ ovate $=44.4 ;$ elliptic $=11.1$ \\
\hline Depth of stalk cavity & Deep $=66.7 ;$ medium $=33.3$ \\
\hline Blotchness & Large $=88.9 ;$ medium $=11.1$ \\
\hline Shape of apex & Truncate $=66.7 ;$ rounded $=33.3$ \\
\hline Presence of mucro & Absent $=66.7$; present $=33.3$ \\
\hline Suture & $\begin{array}{l}\text { Raised }=44.4 ; \text { slightly sunken }=33.3 ; \text { moderately sunken }= \\
22.2\end{array}$ \\
\hline Symmetry & Symmetric $=100$ \\
\hline Ground color of skin & Orange $=44.4$; light orange $=33.3$; Yellow $=22.2$ \\
\hline Presence hue of over color & Pink $=66.7 ;$ Absent $=33.3$ \\
\hline Size of hue & Absent $=33.3 ;$ small $=55.6 ;$ medium $=11.1$ \\
\hline Color of flesh & Light orange $=55.6$; Orange $=44.4$ \\
\hline Flesh consistency & Fine $=100$ \\
\hline Taste & Sweet $=100$ \\
\hline $\begin{array}{l}\text { Adherence of stone to } \\
\text { flesh }\end{array}$ & Absent $=100$ \\
\hline Ratio mass of stone/fruit & Small $=55.6 ;$ medium $=22.2 ;$ large $=11.1$ \\
\hline \multicolumn{2}{|r|}{ Stone } \\
\hline Size & Small $=33.3 ;$ medium $=33.3 ;$ large $=22.2 ;$ very large $=11.1$ \\
\hline Symmetry & Asymmetric $=100$ \\
\hline Shape & $\begin{array}{l}\text { Prolate }=22.2 ; \text { obovate }=22.2 ; \text { ovate }=33.3 ; \text { elliptic }=11.1 ; \\
\text { circular }=11.1 ; \text { oblong }=0 .\end{array}$ \\
\hline Shape of stone base & Narrow $=88.9 ;$ broad $=11,1$ \\
\hline Presence spine by of hole & Absent $=33.3 ;$ present $=66.7$ \\
\hline Form hole shape & Skewness $=100$. \\
\hline Shape of apex & Obtuse $=100$. \\
\hline Thickness & Thin $=11.1 ;$ medium $=77.8 ;$ thick $=11.1$ \\
\hline Ribs width & Broad $=66.7 ;$ medium $=22.1 ;$ narrow $=11.1$ \\
\hline Lateral ribs type & Well-developed $=77.8 ;$ prominent $=22,2$ \\
\hline Surface color & Light brown $=33.3$; brown $=11.1$; dark brown $=55.6$ \\
\hline Keel height & Large $=66.7 ;$ medium $=33.3$. \\
\hline Keel type & Apex $=55.6 ;$ regular $=22.2 ;$ base $=22.2$ \\
\hline Keel character & Acute $=100$. \\
\hline Dorsal suture & $\begin{array}{l}\text { Closed }=11.1 ; \text { Open at base }=22.2 ; \text { Outside apex }=33.3 \text {; } \\
\text { Intermittent }=33.3 \text {. }\end{array}$ \\
\hline Outer surface & Weakly wrinkled $=44.4$; strongly wrinkled $=55.6$ \\
\hline Bitterness & Absent $=100$ \\
\hline
\end{tabular}

Note: bold text for characteristics of Shalakh. 


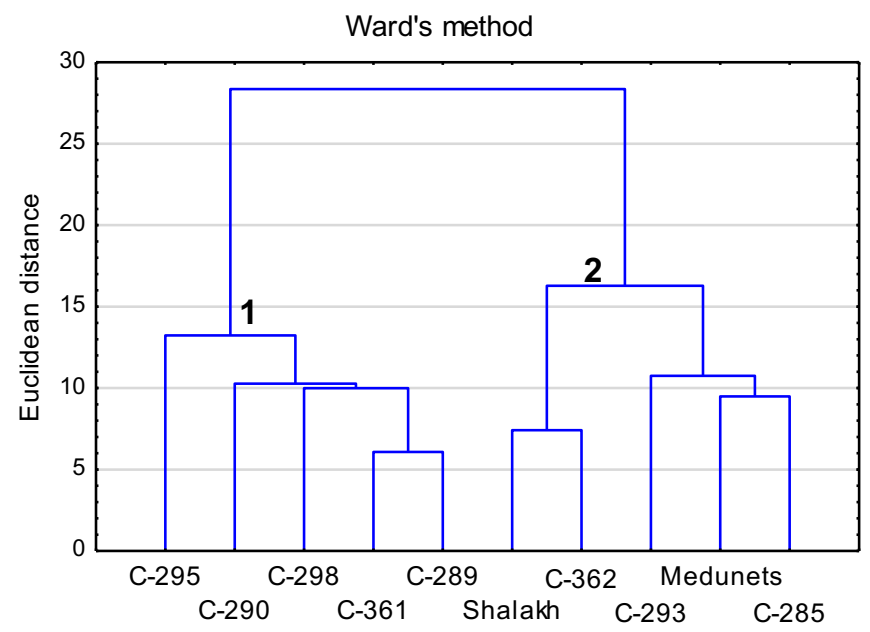

Fig. 1. Clustering of the cultivars of apricot on high-quality traits of fruit and stone

\section{Conclusion}

The best inheritability of the characteristics of the Shalakh cultivars were traits the symmetry of fruit and stone (100\%), form hole shape of stone $(100 \%)$, shape of stone apex $(100 \%)$, keel character $(100 \%)$, blotchness $(88.9 \%)$, shape of stone base $(88.9 \%)$, thickness of stone $(77.8 \%)$, lateral ribs type $(77.8 \%)$, which can serve as diagnostic when recognizing varieties of Shalakh. Bad or almost is not transmitted elliptical form of fruit and elongated shape of stone.

Clustering of samples by the Ward's method made it possible to allocate two clusters differing in the traits: presence of fruit mucro, presence spine by of hole and surface of stone. Most of the traits turned out to be less informative, which may be due to both the limited sampling and the high level of the genetic proximity of the cultivars to each other.

The results of the study of the alarm analysis of the apricot's fruits and stones can be used for identifying varieties, selection, as well as for a better understanding of the inheritance traits of Shalakh hybrids.

Acknowledgments. The work was supported by RFBR grant №19-016-00133A

\section{References}

1. E. Mratinić, B. Popovski, T. Miloševićб M. Popovska, J. Agr. Sci. Tech., 13, 11211134 (2011) https://jast.modares.ac.ir/article-23-3889-en.pdf

2. T.N. Zhebentyayeva, C. Ledbetter, L. Burgos, G. Llácer, In: M. Badenes, D. Byrne (eds) Fruit Breeding, 415-458 (Springer Science+Business Media: New York, 2012). https://doi.org/10.1007/978-1-4419-0763-9_12

3. K.U. Yilmaz, K. Gurcan, In: Mahmut Çalışkan (Ed.) Genetic Diversity in Plants, 249270 (IntechOpen, 2012) http://doi.org/10.5772/33361

4. K.U. Yilmaz, S. Paydaş Kargi, S. Kafkas, Turk. J. Agric. For., 36, 688-694 (2012) https://doi.org/10.3906/SAG-1208-1

5. H. Bourguiba, J. M. Audergon, L. Krichen, N. Trifi-Farah, A. Mamouni, S. Trabelsi, B. Khadari, Sci. Hortic., 142, 7-13 (2012) https://dx.doi.org/10.1016/j.scienta.2012.04.024 
6. H. Bourguiba, A. Lasnier, B. Krška, T. Zhebentyaeva, C. D’Onofrio, C.A. Ledbetter, H. Iketani, D. Christen, W. Liu, G. Roch, J.M. Audergon, Acta Hortic., 1214, 203-206 (2018) https://doi.org/10.17660/ActaHortic.2018.1214.35

7. A. Smykov, E. Shoferistov, V. Korzin, N. Mesyats, N. Saplev, E3S Web Conf., 254, (2021) https://doi.org/10.1051/e3sconf/202125401010

8. Z.M. Asadulaev, D.M. Anatov, M.A. Gaziev, Acta Hortic., 1032, 183-190 (2014) https://doi.org/10.17660/ActaHortic.2014.1032.24

9. Z.M. Asadulaev, D.M. Anatov, Arid Ecosyst., 9(2), 104-110 (2019) https://doi.org/10.1134/S2079096119020021

10. D.M. Anatov, R.M. Osmanov, Z.M. Asadulaev, M.A. Gaziev, Herald of Dagestan State

University,
http://www.vestnik.dgu.ru/pol.aspx?razdel=3\&artId=2929

11. M. Nesheva, V. Bozhkova, J. Mount. Agric. Balk., 21(2), 182-193 (2018) https://www.researchgate.net/publication/328496259

12. I.V. Mitrofanova, O.V. Mitrofanova, N.P. Lesnikova-Sedoshenko, S.V. Chelombit, V.M. Gorina, S.N. Chirkov, Acta Hortic., 1290, 237-242 (2020) https://doi.org/10.17660/ActaHortic.2020.1290.42

13. D.M. Anatov, BIO Web of Conf., 25, 5 (2020) https://doi.org/10.1051/bioconf/20202502011

14. Y. Li, T. Smith, C. J. Liu, N. Awasthi, J. Yang, Y. F. Wang, C.S. Li, Taxon, 60, 555-564 (2011) https://doi.org/10.1002/tax.602021

15. X. Yang, R. Zhang, Z. Zhai, Y. Pang, Z. Jin, Sci. Hortic., 256, 108524 (2019) https://doi.org/10.1016/j.scienta.2019.05.051

16. M. Rezaei, P. Heidari, A. Khadivi, Sci. Hortic., 262, 109062 (2020) https://doi.org/10.1016/j.scienta.2019.109062 